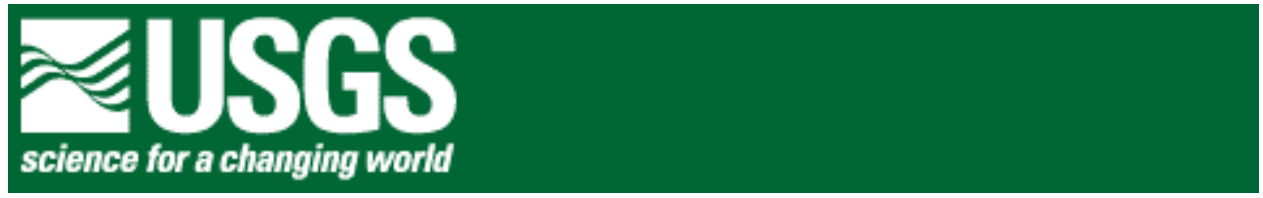

\title{
SPECTRAL INDUCED POLARIZATION MEASUREMENTS AT THE CARLISLE MINE DUMP, NEW MEXICO
}

\author{
by David L. Campbell and Shay Beanland
}

\section{Open-File Report 01-363 2001}

Denver, Colorado

Beanland now at Department of Geological Science, Ohio State University, Columbus OH 43210-1394

This report is preliminary and has not been reviewed for conformity with U.S. Geological Survey editorial standards and stratigraphic nomenclature. Any use of trade, product, or firm names is for descriptive purposes only and does not imply endorsement by the U.S. Government.

\section{U.S. DEPARTMENT OF THE INTERIOR U.S. GEOLOGICAL SURVEY}




\section{SPECTRAL INDUCED POLARIZATION MEASUREMENTS AT THE CARLISLE MINE DUMP, NEW MEXICO}

by David L. Campbell and Shay Beanland

\section{INTRODUCTION}

As part of a project to characterize mine waste, the USGS did integrated geological, geochemical, and geophysical studies of 8 mine dumps in Colorado and New Mexico. One of these was the Carlisle mine dump in the Steeple Rock $71 \frac{1}{2}$-minute quadrangle, southwestern New Mexico (figs. 1, 2). The dump contains mine waste that appears to have been hoisted up a vertical shaft from underground workings. Most of its top is graded level, although there is a depression along its western edge that is as much as about $10 \mathrm{ft}$ deep. This depression may have resulted from caving of an underground opening. The dump material laps onto country rock on its north and east sides and forms a wall as high as $35 \mathrm{ft}$ high at angle of repose on its south and west sides. At the north edge of the dump area is a 60-ft near-vertical cut into an excavated area from which emanate at least three horizontal or down-sloping tunnels, now abandoned (fig. 3).

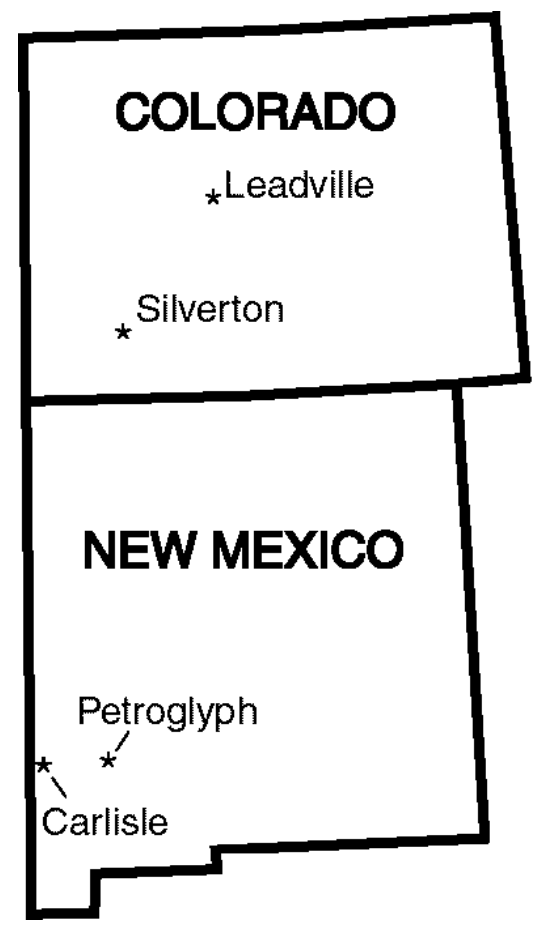

Figure 1. Outline map showing areas of mine dumps studied by the USGS Mine Waste Characterization project. The Carlisle mine dump is in southwestern New Mexico. 


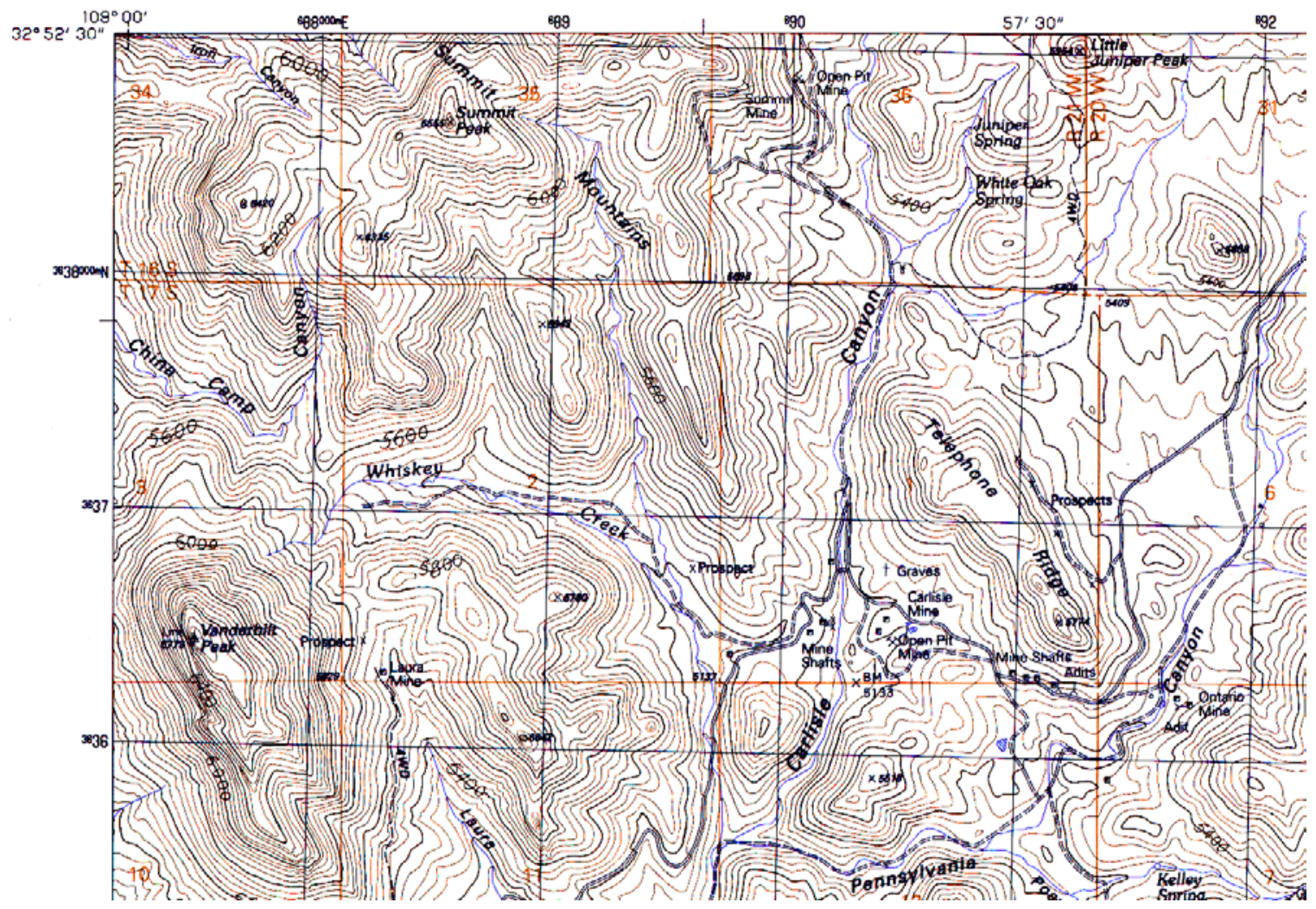

Figure 2. Image of northwestern part of Steeple Rock, New Mexico 7 1/2-minute quadrangle. Carlisle Mine is in the central southeastern part of area shown.

\section{SUMMARY OF GEOCHEMICAL WORK}

Composite mine dump samples were collected from 8 mine waste piles in Colorado and New Mexico, including the Carlisle mine dump, using a procedure described by Smith and others (2000). Desborough and others (in prep.) described the mineralogical compositions of these samples. Hageman and Briggs (2000) compared waters leached from these samples using two methods, the EPA Method 1312 (U.S. Environmental Protection Agency, 1994) and a modified EPA Method 1312 called the Synthetic Precipitation Leaching Procedure (SPLP). Leach water from the Carlisle mine dump composite sample had $\mathrm{pH}=5.45$ when obtained using EPA Method 1312, and $\mathrm{pH}=5.13$ when obtained using SPLP. Smith and others (2000) list amounts of selected metals found in the SPLP leachate water versus particle size fractions for the composite samples. 


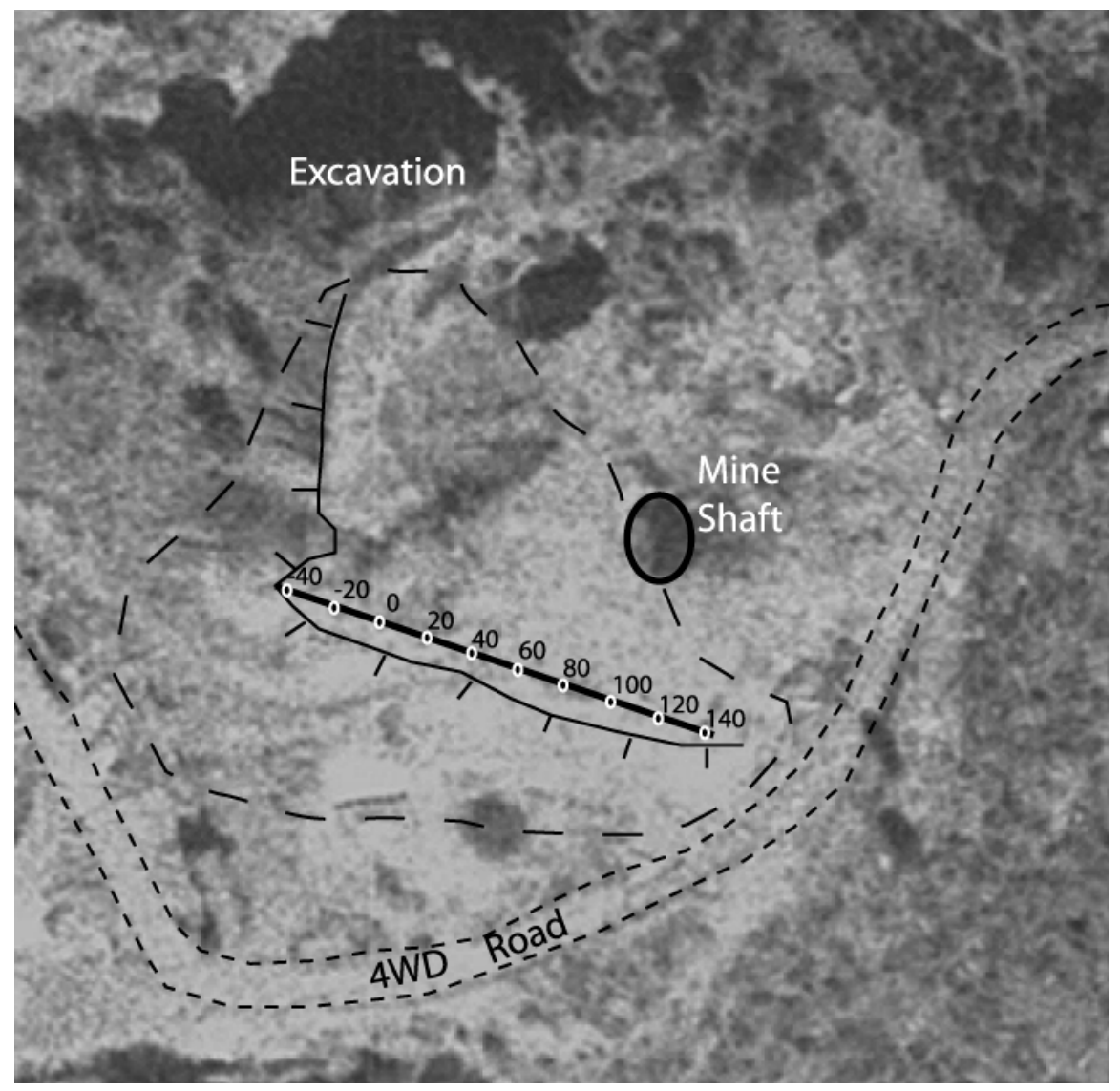

Figure 3. Air photo of Carlisle mine area. Open dashed line approximately encloses the mine waste deposit. Solid line outlines the top of the mine dump; hachures indicate sloping dump face. Heavy bar shows location of the SIP line; labeled points are at $20 \mathrm{ft}$ intervals.

\section{GEOELECTRICAL FIELD MEASUREMENTS}

On July 21, 1999, spectral induced polarization (SIP) measurements were made along a line near the southern part of the level top of the Carlisle mine dump (fig. 3). A Zonge ZT-30 transmitter (Tx) and GDP-32 receiver $(\mathrm{Rx})$ were used in an $\mathrm{N}=5$ pole-dipole configuration with $10 \mathrm{ft}$ dipoles. Resistivity and phase were measured at fundamental frequencies of $1 / 8,1$, and $8 \mathrm{~Hz}$, and at the $3^{\text {rd }}, 5^{\text {th }}, 7^{\text {th }}$, and $9^{\text {th }}$ harmonic of each of these fundamental frequencies, yielding 15-point spectra in the frequency interval from 0.128 to $72 \mathrm{~Hz}$. 


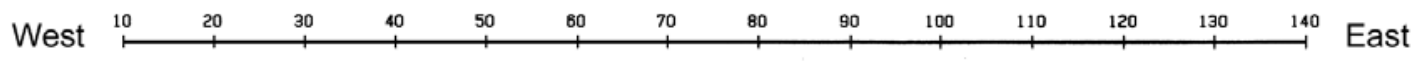
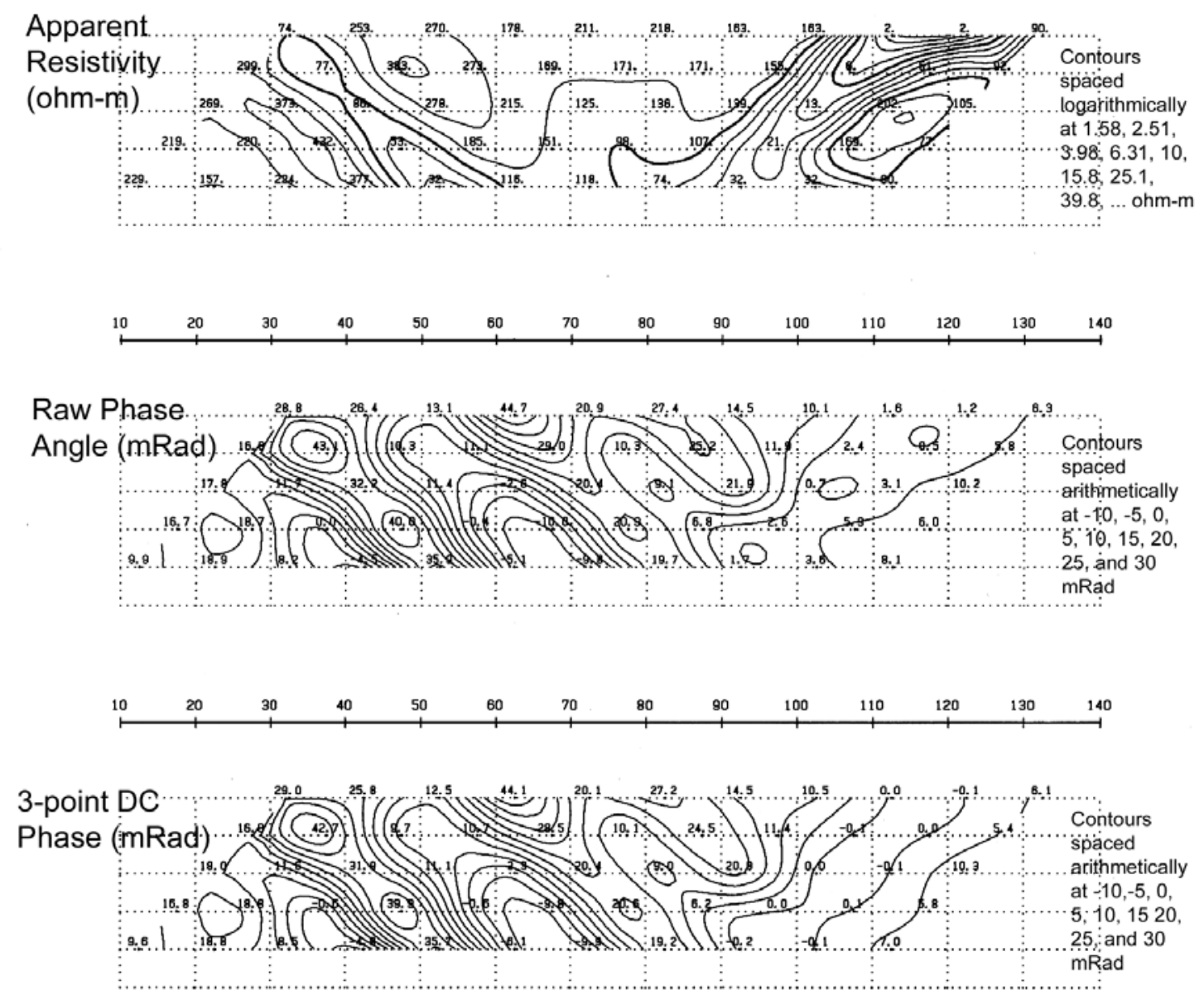

Figure 4. Pseudosections of apparent resistivity (top), raw phase angle (middle), and 3-point DC phase (bottom) measured at the Carlisle mine dump.

Fig. 4 shows pseudosections of the measured apparent resistivity and phase at $0.125 \mathrm{~Hz}$, the lowest frequency used. It also shows "3-point phase", an estimate of the DC phase value based on an extrapolation of values measured at $0.125,0.375$, and $0.625 \mathrm{~Hz}$. Either phase measure can regarded as an IP index, such that higher values indicate more polarizable material. A pseudosection (Sumner, 1976) is a graphical way to show horizontal and vertical variations of measured values along a pole-dipole survey line. To make one, a horizontal line is drawn showing locations of all electrodes. A line is then drawn from the transmitter pole, extending down at an angle of $45^{\circ}$ under the receiver dipoles. Observed values are plotted on this line at the intersections of corresponding $45^{\circ}$ lines from the centers each of the receiver dipoles. Typically, the array of observed values that results is then contoured so as to emphasize variations within it. Such a contour plot does not accurately show true variations in the ground under the section line, however. For example, the bunched contours sloping at $45^{\circ}$ (fig. 4) probably reflect small anomalous masses near the surface that do not extend to depth. In particular, the 
survey line passed near the ruins of a mine installation at coordinates $30-40 \mathrm{ft}$ that may have given rise to the sloping features seen on the west end of the pseudosections.

The apparent resistivity and raw phase data were interpreted using computer program DCIP2D, written at the University of British Columbia-Geophysical Inversion Facility under a consortium research project. DCIP2D is based on work by Oldenberg and Li (1994). The program supposes that the ground under the SIP line consists of an array of continuous blocks, each having its own resistivity and raw phase values. DCIP2D adjusts the properties of these blocks to attain an adequate match to observed values. Figure 5 shows the resulting interpreted section. The precision of the model's values drops off with depth and is lower where there are no pseudosection measurements. Thus, the lower values of interpreted resistivity and raw phase at depth and in zones slanting inward from the sides of the model can be discounted to some extent.

\section{Carlisle Mine}
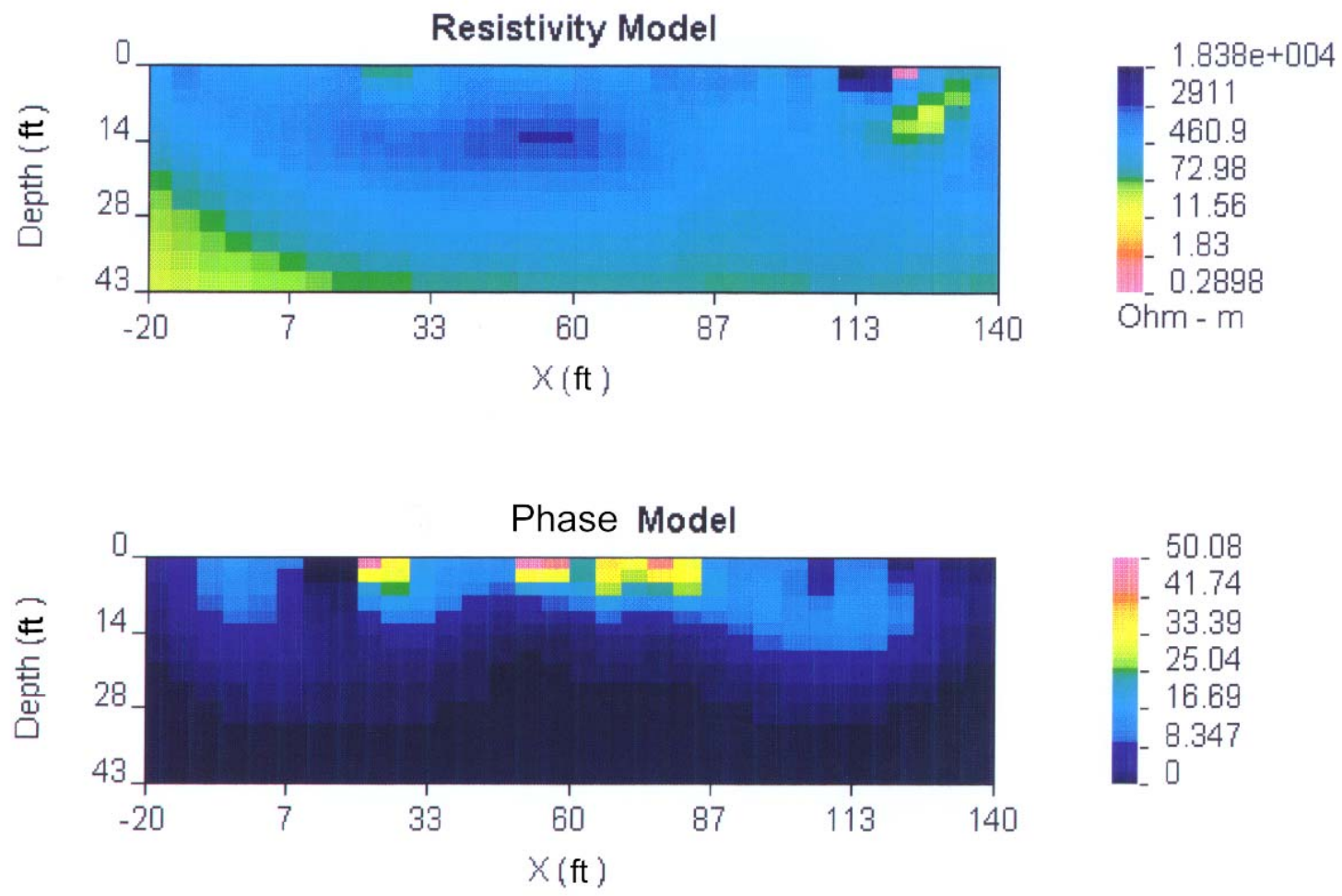

Figure 5. Models showing interpreted resistivity (top) and raw phase (bottom) along the SIP line at the Carlisle mine dump.

The model (fig. 5) shows several anomalous masses very near the surface. The lower resistivity block and the low/high phase blocks around $\mathrm{X}=10-40$ probably reflect the ruined foundation of a mine building (cement with corroded rebar?). A similar shallow resistivity high near $X=120$ may reflect possible buried refuse. The interpreted phase 
highs at $X=\sim 50-90$ indicate the presence there of polarizable material in the shallow subsurface of the dump. Phase highs of this magnitude were also observed at the Yukon mine dump, near Silverton, Colorado, where they were thought to be due to concentrations of metallic sulfide minerals (Campbell and others, 1998; 1999). Here, however, the phase highs have no corresponding resistivity lows. Our work at the May Day mine, also near Silverton, Colorado, led us to infer that local resistivity lows may reflect places in a mine dump where acid mine drainage (AMD) is being generated (Campbell, Horton, and Beanland, 2000). Our interpretation, therefore, is that the Carlisle mine dump contains extensive local concentrations of metallic sulfide minerals, but that substantial AMD is not being produced there. This interpretation is in line with the observations of Desborough and others (in prep.) who report that samples from the Carlisle mine dump typically contain visible galena and pyrite, but they also contain minerals such as calcite that can help neutralize AMD.

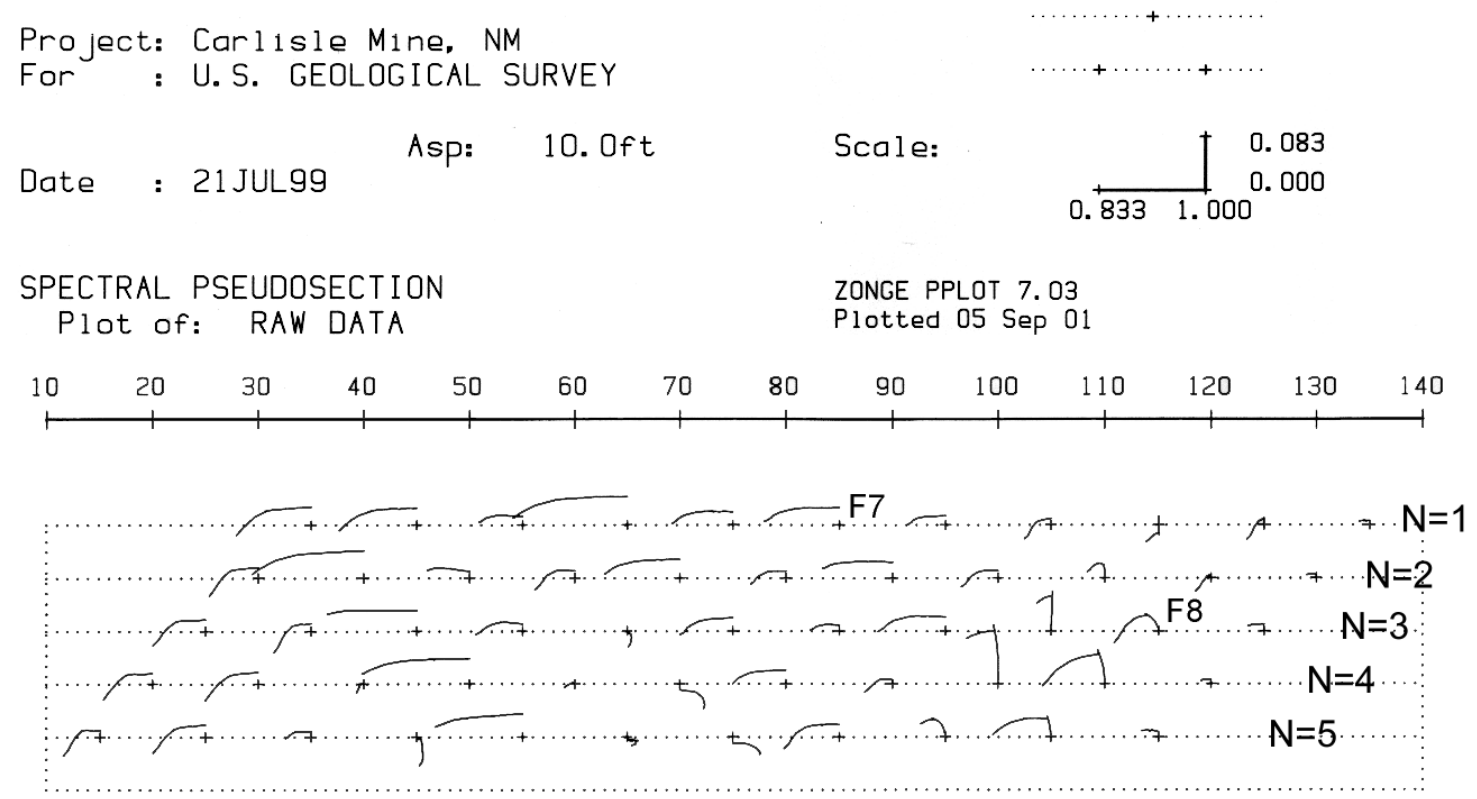

Figure 6. Pseudosection of Argand spectral plots measured at the Carlisle mine dump. All spectra are plotted at the scale indicated in the upper right part of the figure. The spectra include measurements using fundamental frequencies of $1 / 8,1$, and $8 \mathrm{~Hz}$, except that the $8 \mathrm{~Hz}$ series was not measured for Tx pole at $140 \mathrm{ft}$.

\section{SPECTRAL MEASUREMENTS}

Figure 6 is a pseudosection of Argand spectral plots, showing variations in measured spectra along the SIP line. To understand fig. 6, it is helpful to examine some examples of the spectra that appear thereon. Figure 7 shows details of the spectrum labeled F7 on fig. 6 . The right panel shows a standard plot, wherein phase (dashed line) and normalized amplitude (solid line) are graphed as a function of frequency. The left panel has the same data plotted on an Argand diagram, showing real and imaginary components. On both 
panels, asterisk symbols show measured values at the fundamental frequencies of $1 / 8,1$, and $8 \mathrm{~Hz}$, and x's show measured values at the first 4 odd harmonics of these fundamental frequencies. Note that frequency increases to the left along the Argand curve.
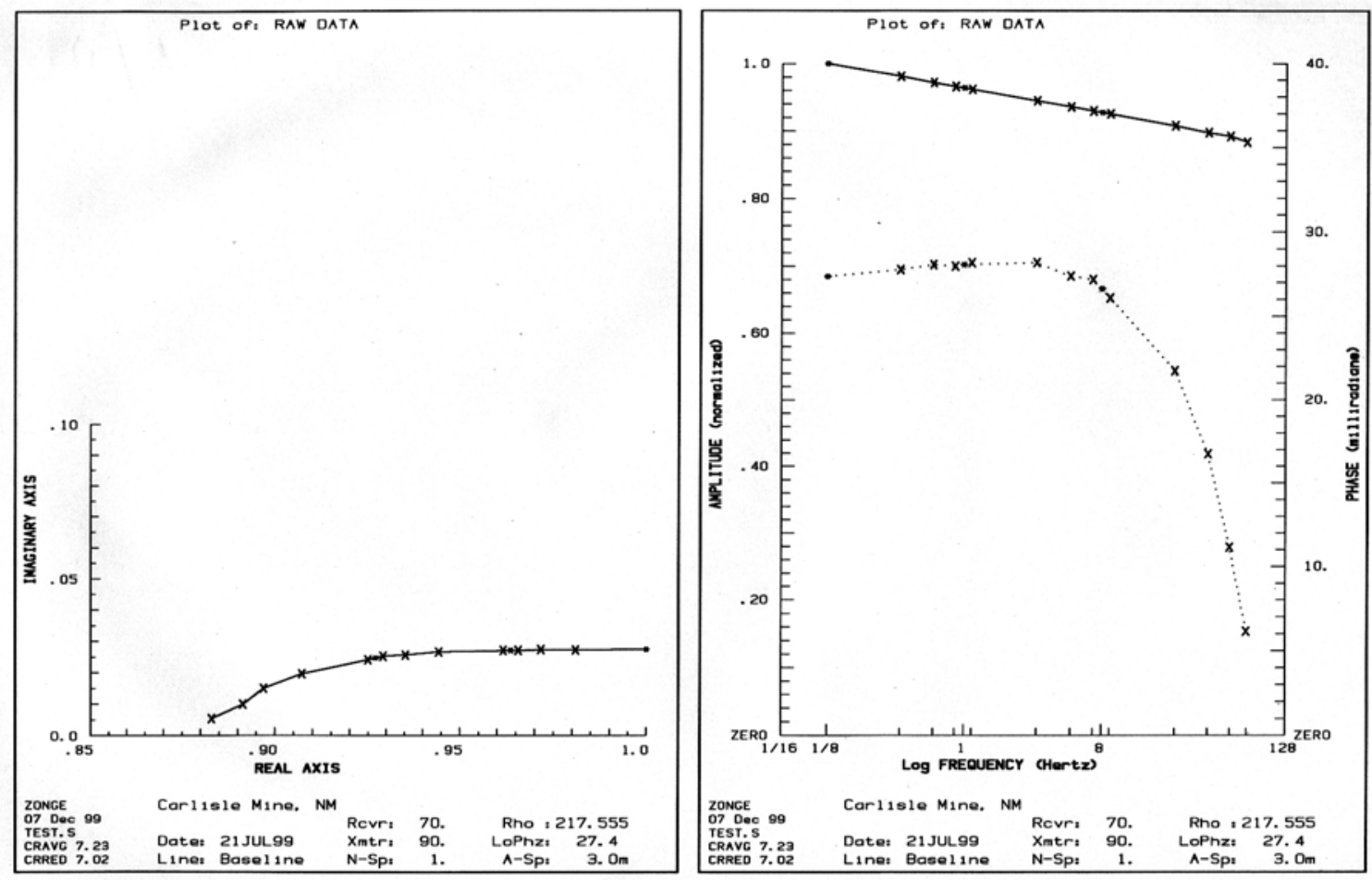

Figure 7. Spectra for $T x$ pole at coordinate $90 \mathrm{ft}$ and $\mathrm{Rx}$ dipole at 70-80 $\mathrm{ft}$ (location F7, fig. 6). Data is plotted on left panel as an Argand diagram, and on right panel versus frequency.

The spectra in fig. 7 are quite flat for the harmonics series that have $1 / 8$ and $1 \mathrm{~Hz}$ as their fundamental frequencies, but the phase (right panel) and imaginary component values (left panel) drop throughout the $8 \mathrm{~Hz}$ series. This latter behavior may be a result of electromagnetic coupling (Wynn and Zonge, 1977), a catch-all term for a number of instrumental and physical effects that can mask the SIP properties of the ground being measured. Electromagnetic coupling effects become stronger and more likely at higher frequencies.

Figure 8 shows the measured spectra at the location marked F8 on fig. 5. There the phase and imaginary component values rise abruptly throughout the $1 / 8 \mathrm{~Hz}$ series, but fall equally abruptly throughout the 1 and $8 \mathrm{~Hz}$ series. Furthermore, the transition between the $1 / 8$ and $1 \mathrm{~Hz}$ series is not smooth, as it should be. Such circumstances lead us to suspect that there may be serious electromagnetic coupling effects at location F8. 

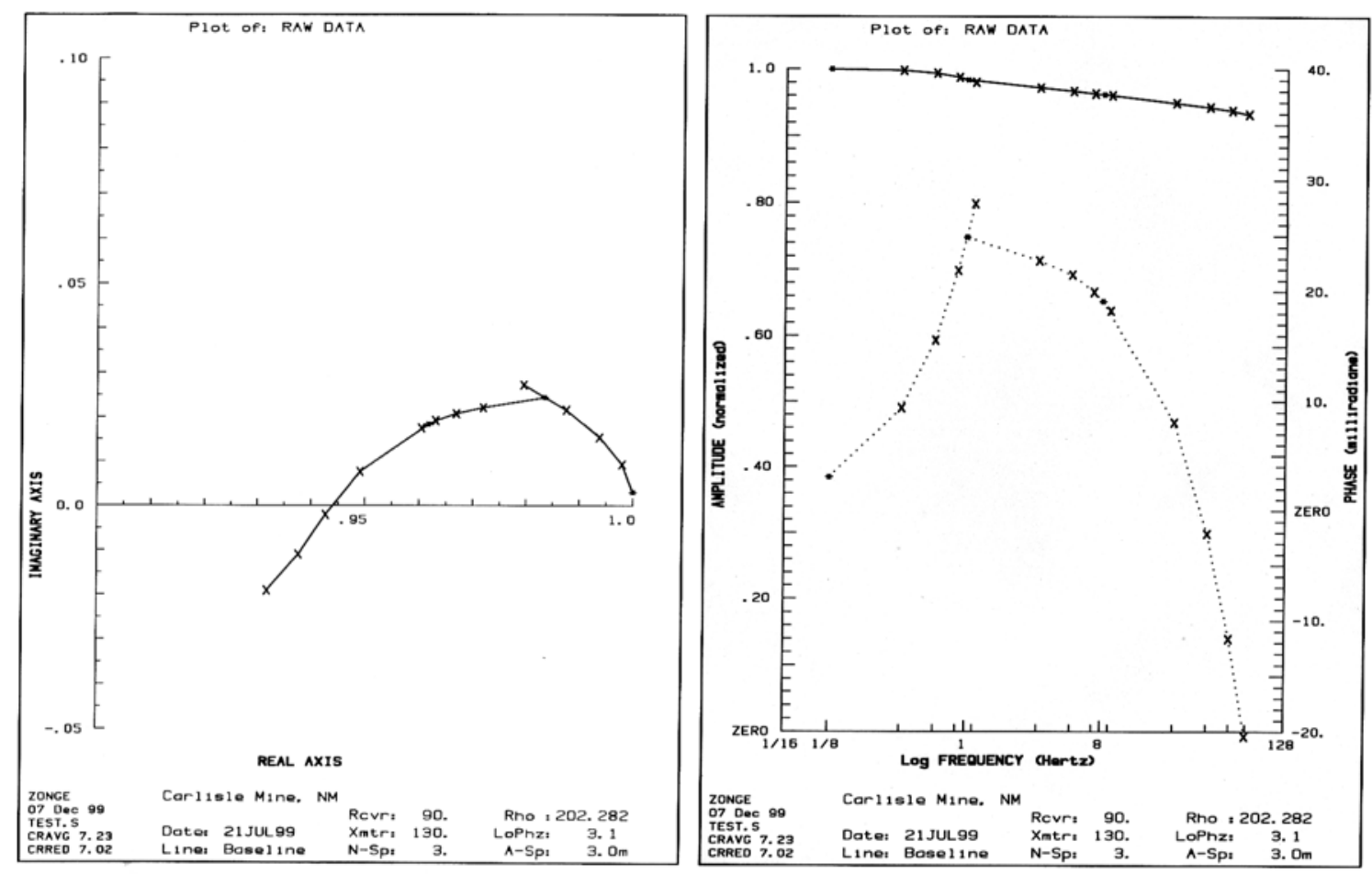

Figure 8. Spectra for $T x$ pole at coordinates $130 \mathrm{ft}$ and $R x$ dipole at 90-100 ft (location F8, fig. 6). Data is plotted on left panel as an Argand diagram, and on right panel versus frequency.

Resistivity and phase spectra were also measured in the USGS Petrophysical Laboratory for the composite sample mentioned above (Anderson and others, 2001). Fig. 9 shows the laboratory spectrum together with the field spectrum taken from fig. 7. Laboratory and field spectra do not correspond very well. Similar mismatches between laboratory and field spectra were found at the Tucson mine dump (Campbell and Horton, 2000a) and at the Main Iron Incline mine dump (Campbell, 2001). Possible reasons for these disparities are discussed by Campbell and Horton (in prep.). The most likely of the reasons listed there is that the current density is much higher in the laboratory measurement than in the field one, so that the electrodes used in the laboratory may have become polarized. 


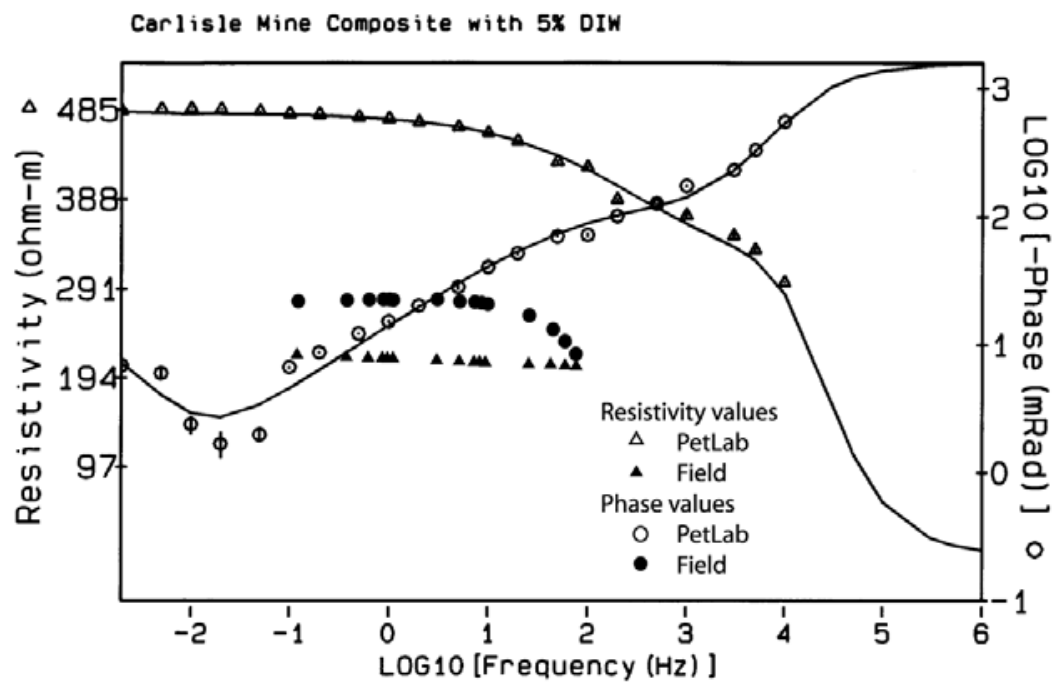

Figure 9. Spectra of material from Carlisle mine dump, as measured in the laboratory (PetLab) and field. The sample measured in PetLab was the composite mine dump sample, rehydrated with de-ionized water to $5 \%$ water content. Solid line is Cole-Cole fit (see Campbell and Horton, 2000b) to PetLab values.

\section{REFERENCES}

Anderson, A.L., Campbell, D.L., and Beanland, Shay, 2001, Laboratory measurements of electrical properties of composite mine dump samples from Colorado and New Mexico: U.S. Geological Survey Open-File Report 01-158, 55 p. http://geology.cr.usgs.gov/pub/open-file-reports/ofr-01-0158

Campbell, D.L., 2001, Spectral induced polarization measurements at the Main Iron Incline mine dump near Leadville, Colorado: U.S. Geological Survey Open-File Report 01-351, 9 p. http://greenwood.cr.usgs.gov/pub/open-file-reports/ofr-01-0315

Campbell, D.L., Fitterman, D.V., Hein, A.S., and Jones, D.P., 1998, Spectral induced polarization studies of mine dumps near Silverton, Colorado: Proceedings of the Symposium on the Application of Geophysics to Engineering and Environmental Problems, March 23-27, 1998, Chicago, Illinois, p. 761-769.

Campbell, D.L., and Horton, R.J., 2000a, Geoelectrical laboratory and field studies of materials from the Tucson Mine dump near Leadville, Colorado: U.S. Geological Survey Open-file report 00-312.

Campbell, D.L., and Horton, R.J., 2000b, Graphs and tables used to describe electrical measurements of samples of unconsolidated material, USGS Petrophysical Laboratory Denver: U.S. Geological Survey Open-file report 00-377.

http://crustal.usgs.gov/minewaste/publications_mine.html 
Campbell, D.L., and Horton, R.J., in prep., Characterization of mine waste materials using spectral induced polarization methods, in Smith, K.S., ed., Screening and characterization of weathered metal-mining waste piles - detailed studies: planned U.S. Geological Survey Professional Paper.

Campbell, D.L., Horton, R.J., and Beanland, Shay, 2000, Geoelectrical laboratory measurements of materials from the May Day Mine dump, southwestern Colorado: U.S. Geological Survey Open-File Report 00-382, 26 p.

http://crustal.cr.usgs.gov/minewaste/publications_mine.html

Campbell, D.L., Horton, R.J., Bisdorf, R.J., Fey, D.L., Powers, M.H., and Fitterman, D.V., 1999, Some geophysical methods for tailings/mine waste work (extended abstract): Tailings and Mine Waste 9 , Proceedings of the Sixth International Conference, Fort Collins, Colorado, January 24-27, 1999; Rotterdam, A.A Balkema, p. 35-43.

Desborough, George A., Leinz, Reinhard W., and Sutley, Stephen J., in prep., Mineralogy and metal mobility of mine waste in the Rocky Mountain region, in Smith, K.S., ed., Screening and characterization of weathered metal-mining waste pilesdetailed studies: planned U.S. Geological Survey Professional Paper.

Hageman, P.L., and Briggs, P.H, 2000, A simple field leach test for rapid screening and quantitative characterization of mine waste dump material on abandoned mine lands: ICARD2000 - Proceedings from the Fifth International Conference on Acid Rock Drainage; Littleton CO, Society for Mining, Metallurgy, and Exploration, Inc., p. 14631475. http://crustal.usgs.gov/minewaste/minewaste pubs.html

Oldenberg, Douglas W., and Li,Yaoguo, 1994, Inversion of induced polarization data: Geophysics, v. 59, no. 9, p. 1327-1341.

Smith, K.S., Ramsey, C.A., and Hageman, P.L., 2000, Sampling strategy for the rapid screen of mine-waste dumps on abandoned mine lands: ICARD2000_Proceedings from the Fifth International Conference on Acid Rock Drainage; Littleton CO, Society for Mining, Metallurgy, and Exploration, Inc., p. 1453-1461. http://crustal.usgs.gov/minewaste/minewaste pubs.html

Sumner, John S., 1976, Principles of induced polarization for geophysical exploration: New York, Elsevier Scientific Publishing Company, 278 p.

U.S. Environmental Protection Agency, 1994, Test methods for evaluating solid waste, physical/chemical methods (SW-846), $3^{\text {rd }}$ edition, update $2 \mathrm{~B}$ : Environmental Protection Agency, National Center for Environmental Publications, Cincinnati, OH 45268, telephone 800-553-6847, order number EPASW-846.3.2B. http://www.epa.gov/epaoswer/hazwaste/test/sw846.htm

Wynn, Jeffrey C. and Zonge, Kenneth L, 1977, Electromagnetic coupling: Geophysical Prospecting, v. 25, p. 29-51. 